\title{
Financial analysis of catfish cultivation feeding with black soldier fly (maggot) at fish-farmers' group TPS3R Kayumanis, Bogor, West Java, Indonesia
}

\author{
Sobariah ${ }^{1, *}$ \\ ${ }^{1}$ Fisheries Extension Study Program, The Jakarta Technical University of Fisheries, Indonesia
}

\begin{abstract}
The demand for fresh catfish in Bogor Regency is very high, causing catfish farmers to take this business opportunity to produce more catfish. Feed contributes about $60 \%$ of operational cost, therefore to reduce the production cost, the farmer uses black soldier fly (maggot) as a supplementary feed for their catfish cultured. This research aims to analyze the business of catfish cultivation using maggot at fish-farmers group TPS3R Kayumanis in Bogor, West Java, Indonesia. The research was conducted from March to April 2021 using observation, interviews, and documentation. The business feasibility of catfish cultivation was done by calculating the revenue cost ratio $(\mathrm{R} / \mathrm{C})$, breakeven point $(\mathrm{BEP})$, and return on investment (ROI). The result showed $\mathrm{R} / \mathrm{C}$ ratio was 1.4 ; $\mathrm{BEP}$ was 361,437 IDR, and ROI was $8.6 \%$. These results indicated that catfish cultivation using maggot as supplementary feed is a feasible catfish business.
\end{abstract}

\section{Introduction}

Indonesia is a country that has a very large population, so it becomes the basis of potential for fishery products, in terms of national fishery products in 2018 reaching 12.39 million tons which includes capture fisheries products of 5.41 tons, aquaculture products of 6.98 tons. Freshwater aquaculture contributed 1.1 million tons, and the remainder was brackish, marine, and aquaculture in floating net cages. The increase in freshwater fishery products was quite rapid at around $11 \%$ per year. As one of the agricultural sub-sectors, fisheries have a fairly important role, especially in efforts to improve the quality and quantity of fishery production to increase people's income and standard of living. The city of Bogor has 406 aquaculture households (RTP), and the production of fishery products in the city of Bogor in 2020 reached 5,056.50 tons. Produced from 6 sub-districts, namely North Bogor District, South Bogor District, East Bogor District, West Bogor District, Central Bogor District, and Tanah Sareal District

Catfish is a freshwater fish that is very popular and easy to cultivate in Indonesia [1]. Freshwater fish production in West Java, especially catfish, still contributes to the biggest

\footnotetext{
* Corresponding author: sobariah.nafis@gmail.com
} 
freshwater fish production, especially in Bogor, accounting for 773 tons per year. Tanah Sareal subdistrict has a freshwater fish farming business with a total production of 845.52 tons and 68 household Fisheries[2]. The high demand for fresh catfish in Bogor city causes catfish farmers to take advantage of this business opportunity to produce more catfish. Because feed contributes to $60 \%$ of the production cost, reducing artificial feed with alternative life feed. Therefore the farmers use Black Soldier Fly (BSF/maggot) as additional feed to increase their income or profit of the catfish business. This study aims to analyze the business of catfish feeding with BSF in Kayumanis, Tanah Sareal, Bogor City, West Java, Indonesia, and to know the business system applied and the feasibility of business by catfish farmers

\section{Materials and methods}

The material and method used in this study are to use a sampling method, namely purposive sampling, which means that the sampling is done intentionally, namely in Tanah Sareal District, which has 11 Kelurahan. There are 9 TPS3R scattered in urban villages, including Cibadak Village, Sukapeace Village, Kelurahan Mekarwangi, Kayumanis Village and Kencana Village. Of the 9 TPS3Rs, the choice is TPS3R Kayumanis, Tanah Sareal District, Bogor City. The reason for the selection and determination of the $3 R$ TPS is that the 3R TPS is already more active and productive in its activities in catfish and maggot cultivation than the other 8 3R TPS. And precisely in the Kayumanis group 3. This type of descriptive research describes the business location, business feasibility in terms of production aspects, organizational and management aspects, and financial aspects. Marketing aspects: Production aspects include production location, raw materials, additional materials, auxiliary materials, and the technology used in the production process. Organizational structure and management include organizational structure, number, and qualifications of workers, while financial aspects include capital requirements, sources of capital, and working capital. Data collection by observation, interviews, and documentation. Research activities are carried out in March - April 2021

According to Nurhasim (2012), the financial analysis used is the analysis with the formulas of the R/C ratio, BEP Rupiah and BEP unit, Paypabac Period, and Return On Investment (ROI). The formula is as follows:

$$
\text { Revenue Cost Ratio }=\frac{\text { Total Revenue }}{\text { Total Cost }}
$$

Break-Even Point is:

$$
\begin{gathered}
\text { BEP }(\text { Rp. })=\frac{\text { Fix Cost }}{\text { Selling Price per Unit }- \text { Variable Cost per unit }} \\
\text { BEP Unit }=\frac{\text { Fixe cost }}{\text { Variable Cost.Sales }} \\
\text { Payback Period }=\frac{\text { Total Investment }}{\text { operating profit }} x \text { years }
\end{gathered}
$$

Return on investment can be calculated by the formula below (Kasmir, 2014):

$$
\mathrm{ROI}=\frac{\text { Earning income After Interest }+ \text { Tax }}{\text { Total Assets }} \times 100 \%
$$




\section{Results}

\subsection{General condition of the area}

The Tanah Sereal sub-district is one of the sub-districts that have very rapid development in Bogor. There are many developments and public facilities, such as home facilities, malls, hospitals, and others. The Tanah sareal sub-district has 11 villages, namely Kelurahan, Cibadak. Cinnamon, Kebonpedes, Kedungbadak, Kedungjaya, Kedungwaringin, Kencana, Mekarwangi, Sukapeace, Sukaresmi, and Tanah Sareal.

Tanah Sereal sub-district has a population of 210,520 men, as many as 106,506 people and women as many as 104,014 people as for fisheries households as many as 68 based on Bogor City 2020 statistical data with a total production of 845.52 tons of cultivation per year, aquaculture that RTP mostly does is fish. Catfish, in addition to cultivation, there are activities for the residents of Tanah Sareal District, namely fishing with 32 RTPs. Tanah Sareal District is one of the sub-districts in Bogor City whose development is rapidly developing as evidenced by the ownership of Economic Facilities and Infrastructure by Village and Type, namely 42 minimarkets/supermarkets. Fruit stalls/grocery shops as many as 460, and restaurants as many as 106 pieces show that Tanah Sareal District is a rapidly developing sub-district city waste, known as TPS3.

\subsection{Maggot cultivation business for fish feed}

Fisheries business, like any other business, needs to implement production management. The goal is to be able to direct the production effort to obtain the best results. The production process is an activity that occurs in the process of goods or services. For a product or output to occur, a production factor/input is needed, so that production can become an activity to convert inputs into outputs[3]. More specifically, production is a business activity that combines various inputs to produce outputs with minimum costs. Production costs are costs incurred to process raw materials into finished products[4]. This business strategy is an activity that starts from planning, implementing to carrying out activities in selling goods or services to consumers to make a profit[5].

The fishery business, which is quite complex, requires careful thinking to avoid unexpected risks. Fisheries activities in the Tanah Sareal sub-district are catfish cultivation because catfish are easy to cultivate and are in great demand by the public because of the nutrients contained in the catfish meat. Still, Thus, catfish feed is quite high in price, so farmers are looking for alternatives to maggot feed which is cultivated by catfish farmers in the Tanah Sareal sub-district, Bogor of the 11 villages in Tanah Sareal sub-district, there are 9 TPS3 spread over several villages as shown in Table 1 below:

Tabel 1.TPS3R Tanah Sareal District Bogor City

\begin{tabular}{clll}
\hline Number & Name & \multicolumn{1}{c}{ Ward } & \multicolumn{1}{c}{ Adress } \\
\hline 1 & TPS3R LANCAR & SUKADAMAI & Sukadamai RT003.Rw002 \\
2 & TPS3R CIBADAK & CIBADAK & Jl. Seremped RT 003/004 \\
3 & TPS3R MUTIARA & KAYUMANIS & Kp. Salabenda RT 002/004 \\
4 & KAYU MANIS & MEKARWANGI & Kp.Mekarwangi \\
5 & TPS3R MEKARWANGI & CIBADAK & Kencana \\
6 & TP 3R KENCANA BKP & KAYUMANIS & Kp. Salabenda RT 002/004 \\
7 & TPS3R KAYUMANIS 2 & KAYUMANIS & Kp. Salabenda RT 002/004 \\
8 & TPS3R KAYUMANIS 3 & CIBADAK & Bukit Cimanggu City blok X \\
9 & TPS 3R Blok X BCC & CIBADAK & Tamansari Persada \\
\hline
\end{tabular}

Source : DLH kota Bogor 2020 
Catfish farming activities in the Kayumanis group, Tanah Sereal sub-district, Bogor City include investment, investment depreciation, fixed costs, and variable costs, which are the production costs of catfish farming [6]. Every business activity will always spend the invested funds [7]. Everything that is done to increase the ability to create/add value to the usefulness of life is an investment. The purpose of investment is to maximize the net present value, maximize the level of profit and reduce risk. This is following business planning to make the company's goals achieve predetermined goals. Investment is an activity where funds are placed in one or more types of assets for a certain period with the hope of obtaining income or increasing the value of investments in the future [8]. The following is the business performance and production performance of the catfish cultivation business in the Kayumanis group, Tanah Sareal District, shown in Tables 2 and 3 below

Table 2. Production data of catfish cultivation at TPS3R Kayumanis, Tanah Sareal District Bogor City

\begin{tabular}{clll}
\hline Number & Description & Volume & Unit \\
\hline 1 & Pool & 2 & Unit \\
2 & Seed Size $9-10$ & 1500 & tail \\
3 & Maggot Feed & 150 & Kg \\
4 & Labor & 1 & Person \\
5 & Chalk & 2 & Kg \\
6 & Salt & 150 & Gram \\
7 & Water Mechine & 1 & Unit \\
\hline
\end{tabular}

Source: Primary data processed in 2021

Business analysis in the field of fisheries examines entrepreneurship to determine the extent of success that has been achieved during the fishery business [9]. As listed in Table 3 below:

Table 3. List of Catfish Cultivation Business Analysis with Maggot Feed-in Kecamtan Tanah Sareal Kota Bogor

\begin{tabular}{|c|c|c|c|c|}
\hline Number & $\begin{array}{c}\text { Description of } \\
\text { Business } \\
\text { Analysis } \\
\end{array}$ & Quantity & Unit & Information \\
\hline 1 & 2 & 3 & 4 & 5 \\
\hline 1 & Investasi & 6.860 .650 & $\mathrm{Rp}$ & TC to yang issued \\
\hline 2 & Fixe Cost & 125.000 & $\mathrm{Rp}$ & From depreciation cost \\
\hline 3 & Variable Cost & 1.360 .650 & $\mathrm{Rp}$ & From the cost of feed, seeds, etc \\
\hline 4 & Production Cost & 1.485 .650 & $\mathrm{Rp}$ & $\mathrm{BT}+\mathrm{BV}$ \\
\hline 5 & Revenue & 2.080 .000 & $\mathrm{Rp}$ & $P \times Q$ \\
\hline 6 & Profit & 594.350 & $\mathrm{Rp}$ & TR-TC \\
\hline 7 & BEP (unit) & 22.59 & $\mathrm{Kg}$ & From BT divided by $1-\mathrm{BV} / \mathrm{s}$ \\
\hline 8 & BEP (Rp) & $361.437,41$. & $\mathrm{Rp}$ & $\begin{array}{l}\text { From FC/selling Price-variable cost } \\
\text { price }\end{array}$ \\
\hline 9 & $\mathrm{R} / \mathrm{C}$ & 1,4 & & $\mathrm{TR} / \mathrm{TC}$ \\
\hline 10 & ROi & 8,6 & $\%$ & Profit /ttl capital x 100\% \\
\hline 11 & $\mathrm{PP}$ & 12 & Kali/siklus & Ttl capital/profit x 1 year \\
\hline 12 & Produksi & 130 & $\mathrm{~kg}$ & $(1 \mathrm{~kg}=10$ fish $)$ \\
\hline 13 & price & 16.000 & $\mathrm{Rp}$ & $\mathrm{CGS}+\%$ profit \\
\hline
\end{tabular}

Source: Primary data processed in 2021

More specifically, production is a business activity that combines various inputs to produce output with minimal costs. A fishery business that is quite complex requires careful thought to avoid unwanted risk [10]. Fishery activities in Tanah Sareal District are catfish cultivation because catfish are easy to cultivate and much in 
demand by the public because of the nutrients in catfish meat. However, catfish feed is quite expensive, so cultivators are looking for alternatives to maggot feed that are cultivated themselves. Tanah Sareal District, Bogor. During cultivation activities, maggot cultivation is carried out simultaneously to meet catfish farming feed. That can be seen from the business analysis in figure 1.

Business analysis of catfish

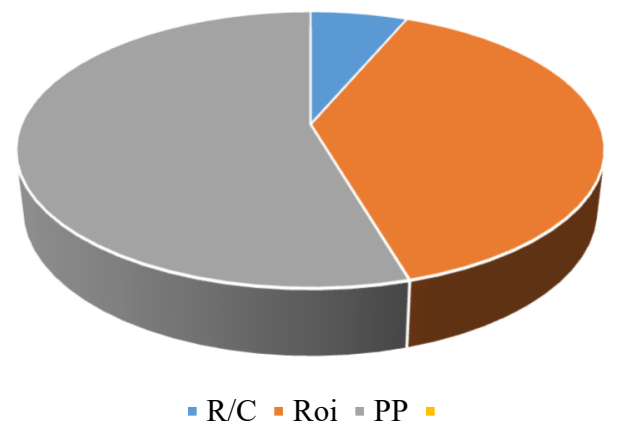

Fig. 1. The results of the analysis of catfish cultivation

$\mathrm{R} / \mathrm{C}$ Ratio (Revenue cost Ratio)

ROI (Return on Investment)

PP (payback period):
: 1.4 means that revenue is greater than production costs, meaning that the business being run is feasible because the $\mathrm{R} / \mathrm{C}$ is more than 1 .

8.6 means that the return on capital used in new business activities is 8.6 , the effectiveness of capital returns have only reached $8.6 \%$,

: 12 means that the capital returns to business activities 12 times or 12 cycles where one cultivation cycle is two months, so the return on capital is about two years

\section{Discussion}

\subsection{General conditions of catfish cultivation}

Maggot feed for fishery activities, namely catfish cultivation, in a 2-meter tarpaulin pond [11]. Tarpaulin is a water-resistant plastic material, which makes it useful as water Tarpaulin ponds are generally used by ornamental fish breeders. The advantages of using tarpaulin ponds include the fact that tarpaulin ponds are easy to build, the pond's temperature is more stable than cement ponds, and it is easier to harvest [12]. This catfish tarpaulin pond does not require a large land area but only requires a yard around the research house [13]. African catfish egg content can reach 30,000-40,000 eggs $/ \mathrm{kg}$ female broodstock, while local catfish are only 1,000-4,000 eggs per kg female parent. Therefore, many African catfish are cultivated in today's society [14]. Moreover, catfish consumption from year to year is increasing.

As with previous research on maggot as an alternative feed put forward by Fauzi, maggot feed is feed given to catfish as an alternative that can reduce production costs for catfish farming [15]. By 50\%, as well as research by Makhrojan M (2019), The results show that maggot can reduce variable costs by up to $53 \%$ and increase the income of fish farming business profits [16]. The research I did where the cultivation of catfish with maggot feed 
can save feed costs of Rp. 8000, - because the price of maggot feed sold in the Bogor area is Rp. 5000, - while the price of pellets is Rp. 13,000. The use of maggot feed provided $150 \mathrm{~kg}$ of the total feed used for catfish cultivation is $150 \mathrm{~kg}$ or $38 \%$ of the total feed given. The production cost is Rp. 1.200,000 per costs production, for that catfish cultivation with maggot feed can save production, this is a solution for catfish farmers in Tanah Sareal District due to the high feed pellets.

\subsection{Financial aspect}

Based on Table 3 above, the results of the analysis of the business activities of catfish cultivators in Kayumanis, Tanah Sareal Regency, show that the R/C ratio obtained by 1.4 businesses is classified as good because the level of income is above costs. The $\mathrm{R} / \mathrm{C}$ is above 1, and the business is still feasible to continue [17]. That the revenue and expenditure activities of production costs can be measured by looking at the comparison between revenues and costs, as well as the break-even point (BEP) proposed by Kasmir, to find and determine the break-even point of a product, can use mathematical models and graphs [18]. BEP unit of $22.59 \mathrm{~kg}$ and Rp. 361,437.4. shows that the production of 22.59 $\mathrm{kg}$ or the same as sales of Rp. 361,437.4, then the business that is run can cover the costs incurred, which shows that the break-even point is $\mathrm{TR}=\mathrm{TC}$, and if the business is below $22.59 \mathrm{~kg}$, production level and sales are below Rp. 361,437.4, then these efforts need to be considered and considered [20].

The payback period used in this cultivation is 12 times/cycle where the cultivation cycle is approximately two years, the business capital can be returned. Judging from the results of these efforts, catfish farming using maggot feed is very promising because it is profitable. As for the advantages, as stated by Ismail Indradi [19], the advantage is what if the revenue is greater than the expenditure of TR-TC with positive conditions, or the difference from TR-TC which produces a positive value, this is following what was experienced by cultivators in Kayumanis 3, which obtained a profit of Rp. 594,350, and also the profit from the difference in feed prices of Rp. 8000, - namely the price of pellet feed of Rp. 13,000/kg, and maggot feed for Rp. 5,000, - so farmers can save production costs of Rp. $8,000 / \mathrm{kg}$, so catfish cultivators can greatly save production costs. This is a sustainable business opportunity because it gets a profit of Rp. 594,350,-plus cost savings of Rp. $748,050=$ then the profit per cycle is Rp. 1,342,400

\subsection{Marketing aspect}

Marketing Aspects According to Kotler, marketing can be divided into five concepts. The fish marketing subsystem can be seen from four basic elements in marketing, namely the $4 \mathrm{P}$ consisting of product, price, place, and promotion. Marketing methods must always be innovative and up to date because experiential marketing offers a valuable strategy for the market. The marketing carried out by the cinnamon group is that they sell their harvests on the spot, namely, buyers come directly to the harvest location, they do not sell it to the market but through a communication network with telephones and they put with prices Rp.16.000,$/ \mathrm{kg}$.

\section{Conclusion}

Catfish farming activities with magot feed can save costs of RP 8000,-/kg of feed. Judging from the economic analysis, obtained R/Cratio of 1.4 means that the business can be profitable because the total revenue is above the total cost, and the profit earned is $\mathrm{Rp}$ 
$594,350 /$ cycle. Still, the profit is greater because there is a production cost savings of Rp. 1.200.000, - and BEP, BEP units can be obtained of $22.59 \mathrm{~kg}$, and rupiah BEP of RP361,437.4, which means that the business reaches the break-even point at production is $22.59 \mathrm{~kg}$. At sales, Rp.361.473, or $\mathrm{TR}=\mathrm{TC}$ at that number, as well as the return on investment used (Payback Period) or PP $=12$ cycles and an ROI of $8.6 \%$ which shows the business productivity reaches $8.6 \%$, which means that the catfish farming business with maggot feed reaches business productivity with efficient use of capital of $8,6 \%$, if the Roi is less than what is currently obtained, the business has less productivity. The efficiency of the use of capital still needs to be considered. After being studied, the catfish farming business with maggot feed is feasible to cultivate when viewed from the overall financial aspect, production aspect, and organizational aspect. Run and develop.

\section{Acknowledgement}

The completion of this paper, of course, has gone through various processes in the preparation of this paper. We would like to thank all parties for the guidance that has provided enthusiasm and motivation in compiling this paper. We also thank all those who have supported us in writing this paper.

\section{References}

1. F. Andreani, J. Manaj. Pemasar. 2, 1 (2007)

2. E.A. Aripin, Undergraduate Thesis, Bandung (ID): Indonesian Computer University (2019)

3. P. Kotler, K.L. Keller, Marketing management (in Bahasa Indonesia) (Erlangga, Jakarta, 2009)

4. A.N. Hidayati, Malia 8, 2 (2017)

5. Imelda, Undergraduate Thesis, Jakarta (ID): Sekolah Tinggi Perikanan (2018)

6. I. Indradi, D. Wijiyanto, T. Yulianto, Suroto, J. Saintek Perikan. 8, 2 (2013)

7. R.D. Judhaswati, O.H. Damayanti, Cakrawala 12, 2 (2018)

8. Kasmir, Financial statement analysis (in Bahasa Indonesia) (Raja Grafindo Persada, Jakarta, 2014)

9. Badan Pusat Statistik Kota Bogor, Bogor City in figures 2020 (BPS, Bogor, 2020)

10. SN. Sudana, IW. Arga, N Suparta, J. Manaj. Agribisnis 1, 1 (2013)

11. R.U.A. Fauzi, E.R.N. Sari, J. Teknologi dan Manajemen Agroindustri 7, 1 (2018)

12. K. Mahyuddin, Harvest carfish in various containers (Penebar Swadaya Grup, Jakarta 2008)

13. M. Manurung, P. Rahardja, Macroeconomic theory (Universitas Indonesia, Jakarta 2001)

14. A.M. Morissan, Integrated marketing communication advertising (Kencana, Jakarta, 2015)

15. S.D. Nugroho, Purwadi, J. Aplikasi Teknik dan Pengembangan Masyarakat 3, 2 (2012)

16. M. Makhrojan, J. Ekon 10, 2 (2019)

17. R. Rahardi, Kristiawati, Nazaruddin, Fishery agribusiness (in Bahasa Indonesia) (Penebar Swadaya Grup, Jakarta, 2008)

18. D. Rosalina, Ilmu Kelaut. 6,1 (2014) 
19. I. Indradi, et.al., J. Saintek Perikanan 8, 2 (2013)

20. Trubus Magazine, Happy gourami on the tarpaulin, https://www.trubusonline.co.id/selamat-gurami-di-atas-terpal/ (2009)

21. I. Sukriyah, Undergraduate Thesis, Cirebon (ID): IAIN Syekh Nurjati Cirebon (2016)

22. H. Umar, Business feasibility study: techniques for comprehensively analyzing feasibility business plans (Gramedia Pustaka Utama, Jakarta, 2009) 